\title{
Commentary
}

\section{Sport-for-Change: Some Thoughts from a Sceptic}

\author{
Fred Coalter \\ Leeds Beckett University, Leeds, UK; E-Mail: fredcoalter@hotmail.co.uk
}

Submitted: 13 January 2015 | Accepted: 13 January 2015 | Published: 25 June 2015

\begin{abstract}
Sport's historic attraction for policy makers has been its claims that it can offer an economy of remedies to seemingly intractable social problems- "social inclusion", "development". Such usually vague and ill-defined claims reflect sport's marginal policy status and its attempts to prove its more general relevance. The dominance of evangelical beliefs and interest groups, who tend to view research in terms of affirmation of their beliefs, is restricting conceptual and methodological development of policy and practice. There is a need to de-reify "sport" and to address the issue of sufficient conditions - the mechanisms, processes and experiences which might produce positive impacts for some participants. This requires researchers and practitioners to develop approaches based on robust and systematic programme theories. However, even if systematic and robust evidence is produced for the relative effectiveness of certain types of programme, we are left with the problem of displacement of scope-the process of wrongly generalising micro level (programme) effects to the macro (social). Although programme rhetoric frequently claims to address social issues most programmes have an inevitably individualist perspective. Further, as participation in sport is closely related to socially structured inequalities, it might be that rather than sport contributing to "social inclusion", various aspects of social inclusion may precede such participation. In this regard academics and researchers need to adopt a degree of scepticism and to reflect critically on what we and, most especially, others might already know. There is a need to theorise sportfor-change's limitations as well as its "potential".
\end{abstract}

\section{Keywords}

displacement of scope; programme theory; scepticism; sport-for-change

\section{Issue}

This commentary is part of the special issue "Sport for Social Inclusion: Critical Analyses and Future Challenges", edited by Dr. Reinhard Haudenhuyse (Vrije Universiteit Brussel, Belgium) and Professor Marc Theeboom (Vrije Universiteit Brussel, Belgium)

(C) 2015 by the author; licensee Cogitatio (Lisbon, Portugal). This article is licensed under a Creative Commons Attribution 4.0 International License (CC BY).

\section{Inflated and Vague Promises}

Despite claims that sport-for-development or sport-forchange is "new", the historic rationale for investment in sport has consistently been based on supposed externalities-sport's presumed ability to teach "lessons for life", to contribute to "character building" (President's Council on Physical Fitness and Sports, 2006) and its supposed ability to contribute to the reduction of a variety of social problems. Sport's attraction for policy makers has been a perception that it can offer an economy of remedies to seemingly intractable social problems (e.g., crime, "social inclusion", "development").
Despite the absence of systematic, robust supportive evidence (Coalter, 2007; President's Council on Physical Fitness and Sports, 2006), sports evangelists have made wide-ranging, if rather vague and illdefined, claims about sport's capacity to address issues of personal and social development. In part this reflects Weiss's (1993) contention that inflated promises are most likely to occur in marginal policy areas which are seeking to gain legitimacy and funding from mainstream agencies. For example, Houlihan and White (2002) contend that sport tends to be opportunistic and reactive-a policy taker and not a policy maker. In such circumstances "holders of diverse values and dif- 
ferent interests have to be won over, and in the process a host of inflated and unrealistic goal commitments are made" (Weiss, 1993, p. 96).

These processes were given a major boost by two broad shifts in social policy in the late 1990s. Firstly, starting in the UK, but soon spreading worldwide (Bloom, Grant, \& Watt, 2005; The Australian Sports Commission, 2006), was a shift from the traditional welfare approach of developing sport in the community, to seeking to develop communities through sport (Coalter, 2007) as sport promoted itself as being able to contribute to the new, ill-defined, "social inclusion" agenda.

The second opportunity arose with the United Nations' embrace of sport to support the achievement of the Millennium Development Goals (MDGs). Like the concept of social inclusion, the MDGs shifted the focus of investment from economic capital to social capital, with a focus on personal and "social inclusion" issuesstrengthening education, improving community safety and social cohesion, helping girls and women and youth at risk and addressing issues of public health (including HIV and AIDS) (Kidd, 2008). Such peoplecentred objectives resonated with many of sport's traditional claims about contributing to personal and social development. However, as with social inclusion, the concept of sport-for-development remains "intriguingly vague and open for several interpretations" (Kruse, 2006, p. 8).

Kruse's comment indicates that, despite sport's new opportunities (and its opportunism), there are a number of unresolved issues with the assertions made by the conceptual entrepreneurs of sport-for-change. For example, Coakley (2011, p. 307) argues much of the rhetoric of sports evangelists can be viewed as "unquestioned beliefs grounded in wishful thinking". Hartmann and Kwauk (2011, pp. 285-286) refer to "anecdotal evidence, beliefs about the impact of sport in sound bites of individual and community transformation, packaged and delivered more often than not by those running the programs".

\section{From Faith to Theory}

Firstly, the presumed developmental impacts and outcomes of such programmes tend to be vague, illdefined and lack the clarity and intellectual coherence that evaluation criteria should have. There is a general conceptual weakness, with a widespread failure to offer precise definitions of "sport"; a failure to consider the nature, extent and duration of participation to achieve presumed impacts; the precise nature of individual impacts (i.e., the effect of sport on participants) and the nature of their presumed causal relationship with outcomes (the resulting individual behaviour change). Such variety and lack of precision raise substantial issues of validity and comparability and reduce greatly the possibility of cumulative research findings.
This conceptual imprecision is accompanied by methodological weaknesses. It must be admitted there are generic methodological difficulties in defining and measuring the impacts and outcomes of many social interventions and attributing cause and effect in any simple and straightforward way. However, such basic issues of social science methods are often ignored, especially by the evangelists. In part this is because some view research in terms of affirmation rather than understanding or critique. In the words of Johan Koss, President of Right to Play, "we invite people to do research into things like sport and development, sport and peace. We need to prove what we say that we do" (van Kampen, 2003, p. 15). Or, UNICEF (2006, p. 1) arguing that there was "a shared belief in the power of sport-for-development [and] a shared determination to find ways to document and objectively verify the positive impact of sport".

These beliefs exist despite the existence of an extensive body of sport and related research which raises fundamental questions about the validity of the overly generalised assertions about sport's capacity to achieve certain developmental impacts (Coalter, 2007). It is significant that such research is frequently ignored on the basis of the spurious, legitimating, claim that this is a "new" area of policy and practice.

More fundamentally and related to the lack of clarity is the issue of sufficient conditions. Participation in "sport", however defined and however provided, is a necessary but not sufficient condition to obtain any supposed benefits. In this regard Coakley (1998, p. 2) argues that we need to regard "sports as sites for socialisation experiences, not causes of socialisation outcomes" and Hartmann (2003, p. 134) argues that "the success of any sports-based social intervention program is largely determined by the strength of its nonsport components". It might be argued that the widespread use of sport plus approaches (Coalter, 2007) indicates a recognition of the developmental limits of "sport". Consequently, there is a need for more systematic, analytical information about the various mechanisms, processes and experiences associated with participation in "sport". We require a better understanding about what sports and sports' processes, produce what impacts, for which participants and in what circumstances. One possible approach to such issues is provided by a theory of change (Granger, 1998), or programme theory (Coalter, 2013a; Pawson, 2006; Weiss, 1997).

A programme theory seeks to identify the components, mechanisms, relationships and sequences of causes and effects which programme providers presume lead to desired impacts and outcomes-a theory of value, attitude and behaviour change. It seeks to understand the nature of sufficient conditions - the processes and experiences necessary to maximise the potential to achieve desired impacts. Such an approach: 
- Assists in the formulation of theoretically coherent, realistic and precise impacts related to programme processes and participants;

- Enables the identification of critical success factors enabling a more informed approach to programme design and management;

- Explores potentially generic mechanisms, thus providing a basis for generalisation in order to inform future programme design.

\section{Displacement of Scope and Structural Inequalities}

However, even if systematic and robust evidence is produced for the relative effectiveness of certain types of programme, even if we can identify the generic mechanisms which enable some programmes to contribute to the personal development of some participants (Coalter, 2013b; Pawson, 2006), we are left with the problem of displacement of scope (Wagner, 1964). This refers to the process of wrongly generalising micro level (programme) effects to the macro (social). This in part relates to old debates within social science about the relationship between the individual and the social, or even between values, attitudes, intentions and behaviour.

Although programme rhetoric frequently claims to address social issues-crime, social exclusion, "development"-most programmes have an essentially, and inevitably, individualist perspective. Weiss (1993, p. 103) suggests that many social interventions fail because they are "fragmented, one-service-at-a-time programs, dissociated from people's total patterns of living". Further, Weiss's (1993, p. 105) more general comment about social policy interventions and their "blame the victim" perspectives can be viewed within the context of sport-for-change programmes:

We mount limited-focus programs to cope with broad-gauge problems. We devote limited resources to long-standing and stubborn problems. Above all we concentrate attention on changing the attitudes and behaviour of target groups without concomitant attention to the institutional structures and social arrangements that tend to keep them "target groups".

In relation to such structural issues the work of Wilkinson and Pickett (2009) raises even more fundamental issues. Their core argument relates to the central importance of the relative inequality of income and low levels of social mobility in explaining a range of social problems. Their data illustrate that many of the problems commonly associated with social exclusion (and to which sport offers solutions)-crime, obesity, poor general health, poor educational performance, weak community cohesion-are strongly correlated with so- cietal levels of relative inequality, with more equal countries having much lower levels of such problems. Further, it is clear that sports participation is related to structural issues underpinning social inclusion. For example, van Bottenburg, Rijnen, \& van Sterkenburg (2005) illustrate that the level of educational achievement is the most important determinant of sports behaviour. Also given the very strong relationship between social class and educational opportunity, it is not surprising that there is a strong relationship between social class and sports participation. Also, the level of female sports participation is clearly strongly correlated with the relative status of women in society (Coalter, 2013c; van Bottenburg et al., 2005)-one which is closely related to levels on inequality.

Such consistent relationships between social structure and sports participation have led one major international review of the effectiveness of sports policy interventions (Nicholson, Hoye \& Houlihan, 2011, p. 305) to conclude that:

It is evident...that government policies designed to increase sports participation have had limited success....Some have had success....within small communities or specific cohorts... [but] the same level of success has not been apparent within the mass population..... it is also clear that governments and researchers don't know enough about the way in which complex systems of organisations function to either induce or disrupt sports participation patterns.

Such persistent differentials raise important issues for policies of 'sport and social inclusion', whose success depends on achieving the necessary condition of increased participation in sport by many socially marginal and consistently "under-participating" groups. In this regard van Bottenburg et al. (2005, p. 208) raise significant questions about using sport to address social issues via an individualistic perspective, by arguing that exercise and sport are thoroughly social phenomena and that "the choice to take part in sport, how, where, what and with whom is directly related to the issue of how people see and wish to present themselves...socio-culturally determined views and expectations also play a role here".

The broad conclusion to be drawn from the above analyses is to reverse the current fashion for arguing that sport can contribute to increased "social inclusion" and suggests that various aspects of social inclusion precede such participation. Further, even if sport provides some degree of individual amelioration for some of these problems, Wilkinson and Pickett $(2009$, p. 26) offer a salutary warning about neo-Liberal, individualized approaches to such problems:

Even when the various services are successful in stopping someone reoffending...getting someone 
off drugs or dealing with educational failure, we know that our societies are endlessly re-creating these problems in each new generation.

\section{A Need for Scepticism}

Black (2010, p. 122) argues that the recent expansion of sport-for-development policy and practice has not been underpinned by "critical and theoretically-informed reflection" and others have suggested that there is a need to step back and to reflect critically on what we and, most especially, others might already know (Coakley, 2011; Crabbe, 2008; Tacon, 2007). In this regard Portes $(2000$, p. 4) argues that "gaps between received theory and actual reality have been so consistent as to institutionalize a disciplinary skepticism in sociology against sweeping statements, no matter from what ideological quarter they come". The need for scepticism is nowhere more relevant than in the area of sport-for-change. Such an approach can contribute to the intellectual and practical development of sport-for-development by placing it within a much wider world of knowledge and research and by theorising its limitations as well as outlining its "potential".

\section{Conflict of Interests}

The author declares no conflict of interests.

\section{References}

Australian Sports Commission. (2006). The case for sport in Australia. Canberra: Australian

Sports Commission.

Black, D. (2010). The ambiguities of development: Implications for "development through

Sport". Sport in Society, 13(1), 121-129.

Bloom, M., Grant, M., \& Watt, D. (2005). Strengthening Canada: The socio-economic

benefits of sport participation in Canada. Ottawa: Conference Board of Canada.

Coakley, J. (1998). Sport in society: Issues and controversies (6th ed.). Boston, MA: McGraw Hill.

Coakley, J. (2011). Youth sports: What counts as "positive development?" Journal of Sport and Social Issues, 35(3), 306-324.

Coalter, F. (2007). Sport a wider social role: Who's keeping the score? London: Routledge.

Coalter, F. (2013a). Sport for development: What game are we playing? London: Routledge.

Coalter, F. (2013b). "There is loads of relationships here": Developing a programme theory for sportfor-change programmes. International Review for the Sociology of Sport, 48(5), 594-612.

Coalter, F. (2013c). Game plan and the spirit level: The class ceiling and the limits of sports policy? International Journal of Sport Policy, 5(1), 13-19.
Crabbe, T. (2008). Avoiding the numbers game: Social theory, policy and sport's role in the art of relationship building. In M. Nicholson \& R. Hoye (Eds.), Sport and social capital. London: Elsevier

Granger, R. C. (1998). Establishing causality in evaluations of comprehensive community initiatives. In K. Fulbright-Anderson, A. C. Kubisch, \& J. P. Connell (Eds.), New approaches to community initiatives, volume 2: Theory, measurement and analysis. Washington, DC: Aspen Institute. Retrieved from http://www.aspenroundtable.org/vol2/granger.htm

Hartmann, D. (2003). Theorising sport as social intervention: A view from the grassroots. Quest, 55, 118-140

Hartmann, D., \& Kwauk, C. (2011). Sport and development: An overview, critique and reconstruction. Journal of Sport and Social Issues, 35(3), 284-305.

Houlihan, B., \& White, A. (2002). The politics of sports development: Development of sport or development through sport? London: Routledge.

Kidd, B. (2008). A new social movement: Sport for development and peace. Sport in Society, 11(4), 370380.

Kruse, S. E. (2006). Review of kicking AIDS out: Is sport an effective tool in the fight against HIV/AIDS? (draft report to NORAD, unpublished).

Nicholson, M., Hoye, R., \& Houlihan, B. (Eds.). (2011). Participation in sport: International policy perspectives. London: Routledge.

Pawson, R. (2006). Evidence-based policy: A realist perspective. London: Sage.

Portes, A. (2000). The hidden abode: Sociology as analysis of the unexpected. 1999 presidential address. American Sociological Review, 65, 1-18.

President's Council on Physical Fitness and Sports. (2006). Sports and character development. Research Digest Series, 7(1), 1-8.

Tacon, R. (2007). Football and social inclusion: Evaluating social policy. Managing

Leisure: An International Journal, 12(1), 1-23.

UNICEF. (2006). Monitoring and evaluation for sportbased programming for development: Sport recreation and play (Workshop Report). New York: UNICEF.

van Bottenburg, M., Rijnen, B., \& van Sterkenburg, J. (2005). Sports participation in the European Union. Nieuwegein: Arko Sports Media.

van Kampen, H. (Ed.). (2003). A report on the expert meeting "the next step" on sport and development. Amsterdam: NCDO. Retrieved from http://www.toolkitsportdevelopment.org/html/res ources/0E/0E00BE53-2C02-46EA-8AC5-

A139AC4363DC/Report\%20of\%20Next\%20Step\%20 Amsterdam.pdf

Wagner, H. L. (1964). Displacement of scope: A problem of the relationship between small-scale and large-scale sociological theories. The American Journal of Sociology, 69(6), 571-584.

Weiss, C. H. (1993). Where politics and evaluation re- 
search meet. Evaluation Practice, 14(1), 93-106.

Weiss, C. H. (1997). How can theory-based evaluation make greater headway? Evaluation Review, 21(4), 501-524.

\section{About the Author}

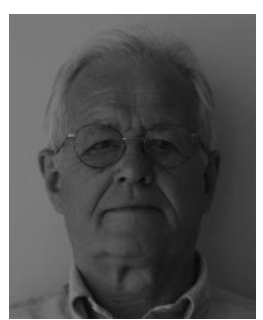

\section{Dr. Fred Coalter}

Fred Coalter is visiting Professor of Sports Policy at Leeds Metropolitan University and was previously a Professor of Sports Policy at the University of Stirling. His research interests relate to sport's claimed contributions to various aspects of social policy. His published work includes Sport-indevelopment: A monitoring and evaluation manual (UK Sport, UNICEF, 2006), A wider social role for sport: Who's keeping the score? (Routledge, 2007), Sport-for-development impact study (Comic Relief, UK Sport, IDS, 2010) and Sport-for-development: What game are we playing? (Routledge, 2013). 